Vol. 3, Issue 3, October 2020

\title{
A Strategy for Sustained Outreach in the Molecular Biosciences
}

\author{
Judy Baeten, Diane Munzenmaier, Gina Vogt, Mark Hoelzer, and Tim Herman \\ Center for BioMolecular Modeling, Milwaukee School of Engineering, Milwaukee, WI \\ Keywords: Physical Models, Protein Modeling, 3D Printing, SMART Teams, SEPA, Professional Development \\ Publication Date: October 21, 2020 \\ DOI: https://doi.org/10.15695/jstem/v3i3.02
}

\begin{abstract}
One goal of the NIH SEPA (Science Education Partnership Awards) program is to create partnerships among biomedical researchers, teachers and schools. The MSOE Center for BioMolecular Modeling (CBM) has leveraged the support from a series of SEPA awards to create a multifaceted outreach program that connects biomolecular researchers and their stories of active research with middle and high school teachers and the foundational concepts of chemistry and biology they teach. 3D printing is the enabling technology that supports this outreach program. For twenty years the CBM has pioneered the use of $3 \mathrm{D}$ printing to create physical models of proteins that engage teachers and students as active participants in the process of science, while at the same time allowing researchers to tell the story of their research project. Here we discuss the key components of our outreach program and how we've overcome challenges to sustaining the program for twenty years.
\end{abstract}

\section{INTRODUCTION}

The Center for BioMolecular Modeling (CBM) at the Milwaukee School of Engineering is an instructional materials development and outreach laboratory. The CBM was created in 1999 as an organization dedicated to teacher professional development in the biomolecular sciences. Developed by former biochemistry researchers who recognized the power of physical models, the CBM sought to use 3D models to explore the invisible world of complex molecular structures and capture the interest of teachers and their students (Roberts et al., 2005; Bain et al., 2006; Herman et al., 2006; Herman et al., 2008). Physical models can be powerful classroom tools because they are engaging (Ainsworth, 1999; Cooper and Oliver-Hoyo, 2017; Gabel and Sherwood, 1980; Harris et al., 2009; Harrison and Treagust, 2000; Herman et al., 2006; Roberts et al., 2006) and they serve as a physical embodiment of a shared mental model (Gilbert, 2005; Babilonia-Rosa et al., 2018). Students prefer physical models to view and manipulate structures in three dimensions (Harris et al., 2009; Larsson and Tibell, 2015; Roberts et al., 2006). Printing of 3D molecular models was made possible by the development of rapid prototyping technology in the 1990's, which was in its infancy during the onset of the CBM's outreach program. Soon the CBM's teacher outreach program evolved to include a student outreach component. Interest in using physical models of biomolecules like proteins and nucleic acids in educational settings has continued to increase in recent years as low-cost 3D printing technology has become available to many schools in the US. This technology has allowed student modeling projects to become more widely accessible and adoptable by teachers and students at various levels around the country and prompted the development of a CBM summer course dedicated to 3D Printing in the Molecular Bioscience Classroom.

The CBM teacher professional development program has always been grounded in both models-based and inquiry-based pedagogy with the aim of using physical models to generate authentic questions about the process of science. Next Generation Science Standards (NGSS) serve as a framework for how science can be taught more effectively at the K-12 level. Developing and Using Models, Asking Questions, Constructing Explanations, and Obtaining, Evaluating and Communicating Information are key NGSS Science and Engineering Practices (NGSS Lead States, 2013; NSTA, 2015) that are aligned with CBM professional development and outreach programs. In addition, Gilbert and Justi describe increasing levels of complexity in model usage; rang- 

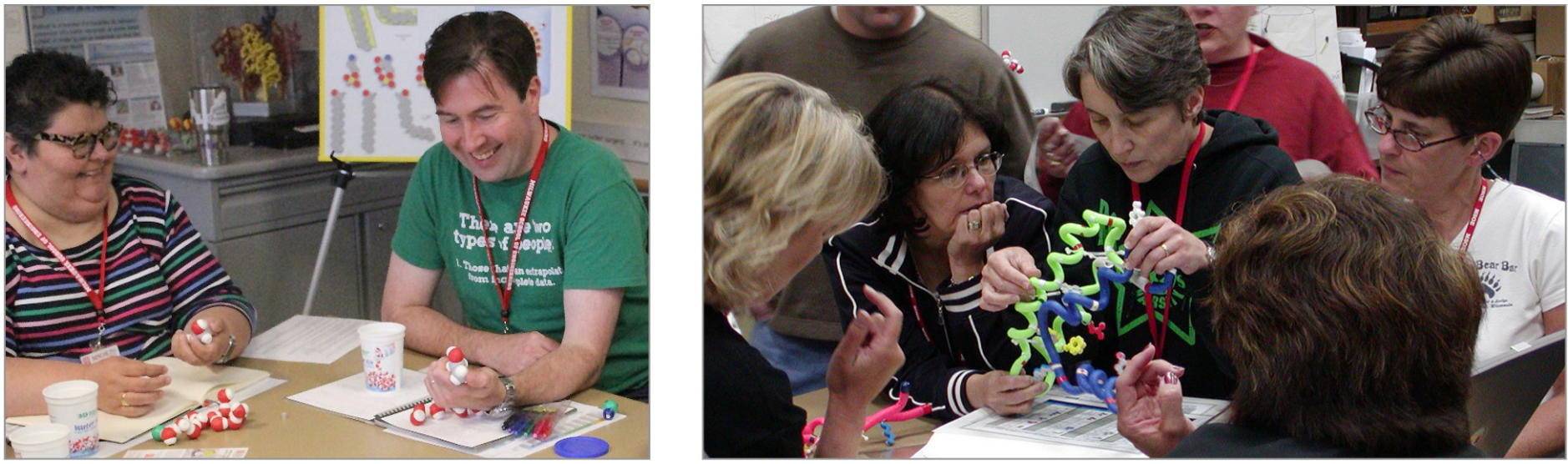

Figure 1. Teachers use physical models to explore proteins and other molecular structures in the Modeling the Molecular World workshop.

ing from learning a model, using a model, to revising and reconstructing a model, and learning to construct a model de novo (Gilbert and Justi, 2016). Each of these targeted learning goals is well developed in student modeling projects implemented at the CBM.

Additionally, Passmore et al. (2014) describe models as "the functional units of scientific thought," and explain that scholars are rethinking how to evaluate scientific practices. Instead of seeing science as a "singular, logical system for knowledge generation and evaluation" (Passmore et al., 2014), educators should seek to more accurately analyze and describe what scientists do in their day to day work. The traditional approach to teaching the fixed and linear "scientific method" often turns off students who might otherwise have an interest in science and STEM related careers. This has sparked a need for science curricula to become more authentic and reflect the process of science (Passmore et al., 2014). CBM modeling programs often involve collaboration with researchers who not only share the story of their research, but also communicate how the process of science works in their laboratories.

In this paper, we address how CBM teacher professional development and student modeling teams explore the process of science and work through various levels of model development, culminating in student-designed physical models of proteins that help communicate a molecular story about structure and function. We will also discuss both the successes and challenges that the CBM has faced in sustaining this program for over twenty years.

\section{PROGRAM DESCRIPTION}

Professional Development for Teachers.

Physical Models and Molecular Stories Help Sustain Relationships with Teachers. The ongoing philosophy of the CBM has always been "Teachers First." We perceived the best way to impact students was to first work with teachers to enhance their content knowledge and teaching practices with the expectation that the impact would be amplified to their students. To that end, the flagship CBM course Modeling the Molecular World was developed and has remained the primary vehicle by which teachers begin to embark on their journey of molecular modeling. Starting in 1999 under its original name, Genes, Schemes and Molecular Machines, this five-day summer professional development workshop has evolved over time, but the primary tenets have remained the same. The focus of this workshop is to establish the foundational concepts of chemistry and biology that provide the underpinning of modern molecular biology (Loertscher et al., 2014). Topics are explored using tactile, physical models of molecular structures in a way that connects structure with function.

Teachers spend the majority of their time in the course with 3D molecular models in their hands. The course begins with teachers exploring the process of science and the basic properties of water (Figure 1), phospholipids, amino acids and nucleotides. Important connections are made when the properties of water are analyzed more critically and extrapolated to include their impact on protein folding. Next, participants tackle the complex process of gene expression and protein synthesis by modeling the flow of genetic information. Throughout the course, teachers are exposed to a new way of teaching biochemistry via "molecular stories." With a phenomenon-based learning approach a specific protein such as insulin or hemoglobin is introduced, and teachers are provided with resources to explore the process of science that led to the discovery of these molecular structures, including analysis of primary literature and data. To enable the process of modeling these molecular stories, CBM staff provide training on using 3D molecular visualization software (Jmol) to design a model of the protein that can be $3 \mathrm{D}$ printed. In this workshop, content is delivered in a way that demonstrates an active-learning pedagogy, encouraging teachers to think deeply and ask questions about the process 


\begin{tabular}{|c|c|c|c|}
\hline Program Activity & SEPS & CCCs & DCls \\
\hline $\begin{array}{l}\text { Modeling foundational } \\
\text { concepts of protein } \\
\text { biochemistry }\end{array}$ & $\begin{array}{l}\text { - Developing and using } \\
\text { models }\end{array}$ & $\begin{array}{l}\text { - Patterns } \\
\text { - Scale, proportion and } \\
\text { quantity } \\
\text { - Cause and effect } \\
\text { - Systems and models } \\
\text { - Structure and function }\end{array}$ & $\begin{array}{l}\text { - LS1.A: Structure and } \\
\text { function } \\
\text { - LS3.A: Inheritance of } \\
\text { traits } \\
\text { - LS3.B: Variation of } \\
\text { traits }\end{array}$ \\
\hline $\begin{array}{l}\text { Analyzing primary } \\
\text { science literature, } \\
\text { collaborating with } \\
\text { research mentors and } \\
\text { writing scientific } \\
\text { abstracts }\end{array}$ & $\begin{array}{l}\text { - Asking questions } \\
\text { - Obtaining, evaluating } \\
\text { and communicating } \\
\text { information } \\
\text { - Analyzing and } \\
\text { interpreting data }\end{array}$ & - Structure and function & \\
\hline $\begin{array}{l}\text { Designing 3D models } \\
\text { of proteins }\end{array}$ & $\begin{array}{l}\text { - Developing and using } \\
\text { models } \\
\text { - Analyzing and } \\
\text { interpreting data }\end{array}$ & $\begin{array}{l}\text { - Patterns } \\
\text { - Scale, proportion and } \\
\text { quantity } \\
\text { - Cause and effect } \\
\text { - Systems and models } \\
\text { - Structure and function }\end{array}$ & $\begin{array}{l}\text { - LS1.A: Structure and } \\
\text { function } \\
\text { - LS3.A. Inheritance of } \\
\text { traits } \\
\text { - LS3.B: Variation of } \\
\text { traits }\end{array}$ \\
\hline $\begin{array}{l}\text { Designing } \\
\text { presentations and } \\
\text { communicating } \\
\text { molecular stories to an } \\
\text { audience }\end{array}$ & $\begin{array}{l}\text { - Asking questions } \\
\text { - Constructing } \\
\text { explanations and } \\
\text { designing solutions } \\
\text { - Obtaining, evaluating } \\
\text { and communicating } \\
\text { information }\end{array}$ & & \\
\hline
\end{tabular}

Figure 2. CBM modeling program activities align with NGSS.

of science and the structure-function relationship in biological molecules. As participants read complex primary literature, some for the very first time, they are encouraged to ask "How do we know what we know?" Teachers collaborate as they discuss how an experiment was done, and how the data was interpreted. Once the teachers have developed a thorough understanding of the protein's structure, they design a physical model of the protein with features that emphasize the molecular mechanism whereby the protein performs its function. Additionally, as participants hold 3D models of these structures in their hands, they practice explanations of how the molecule's structure lends itself to its function. For more information on the Modeling the Molecular World course, visit our website at https://cbm.msoe.edu/teacherWorkshops/mmwResources/.

With the recent development and widespread adoption of
NGSS, the CBM has made it a priority to highlight ways in which the activities and pedagogies practiced in our outreach programs are aligned with these standards. When teachers and students research and communicate a molecular story, they are tackling several NGSS disciplinary core ideas (DCIs), cross-cutting concepts (CCCs), and science and engineering practices (SEPs), including: (i) connecting structure and function; (ii) analyzing and interpreting data; (iii) obtaining, evaluating and communicating information; and (iv) observing patterns, cause and effect (Figure 2).

CBM courses, workshops and modeling programs differ from many other outreach programs in one important way. We do not ask teachers or students to engage in traditional "wet lab" experiences such as PCR or agarose gel electrophoresis. Instead, they explore other aspects of what it is to be a scientist as they immerse themselves in the literature 




Figure 3. The first physical model of a ribosome, based on atomic coordinates, built by $3 \mathrm{D}$ printing technology in the $\mathrm{CBM}$.

surrounding a research topic and begin to outline its molecular story. Molecular stories can serve as phenomena with which teachers authentically engage students' interest. Many teachers appreciate this kind of rigorous professional development that not only strengthens their content knowledge, but also hones their data analysis skills.

\section{Sustained Teacher Engagement Encourages Longevity.} The initial development of Modeling the Molecular World was supported by a series of SEPA grants until 2014. Since then, it has been offered as a fee-based course. The fee covers the cost of housing, some meals, and a collection of physical models and hands-on teaching materials for teachers to take back to their classrooms. The salary of CBM staff who develop and teach this course has been provided by our institution, the Milwaukee School of Engineering, which has valued CBM outreach efforts.

Teachers are willing to pay these fees to attend a professional development workshop because they value the instructional materials they receive. School districts are often willing to cover the cost of course fees, knowing that the teachers will receive training and their classrooms will become better equipped with engaging hands-on materials. The Milwaukee School of Engineering also awards course participants professional educator credits (non-degree), at no additional cost. Course participants are a mixture of local educators and those from across the United States and Canada. The course attracts teachers from middle school through college, teachers of biology, chemistry, and physics, and both new and veteran teachers. The number of participants per cohort has ranged from 24-36 participants per summer. After twenty summers, this professional development program has reached well over 400 teachers.

This introductory course can signal the beginning of a teacher's multi-year pathway through molecular modeling, as it serves as a prerequisite for advanced summer courses. These advanced courses were also developed with the sup-

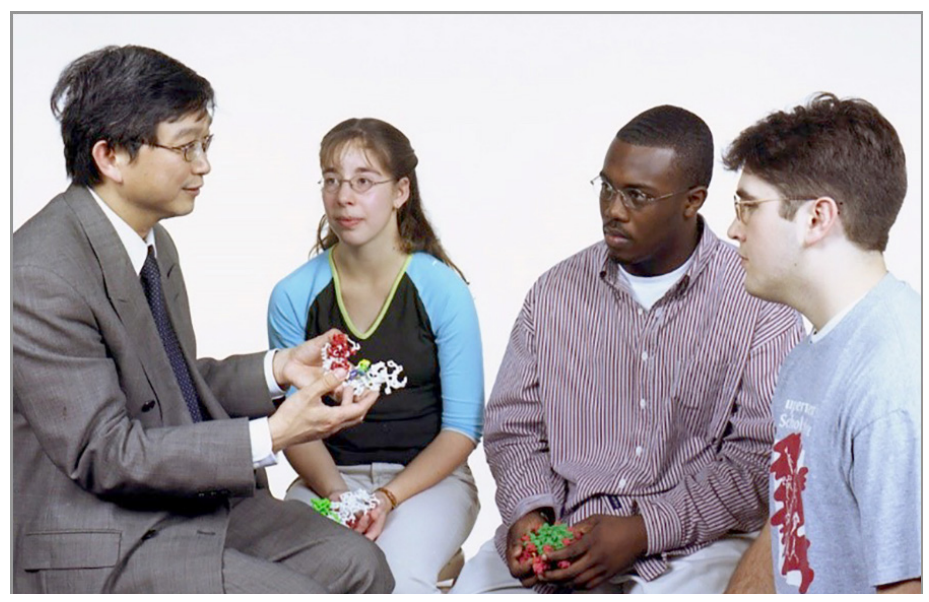

Figure 4. Wei-Jen Tang visits the Riverside high school SMART Team to discuss anthrax models.

port of a series of three successive SEPA awards focused on the topics of (i) Molecular Stories of Research-based Health Care, (ii) Genes, Genomes and Personalized Medicine, and (iii) The Science and Ethics of CRISPR-based Genome Editing. Based on our previous experience in transitioning grant-supported workshops into fee-based workshops, we believe that it will be possible to do this with our advanced courses.

Another important factor in sustaining these professional development courses as they transition from grant-funded to fee-based has been our unique relationship with our sister organization, 3D Molecular Designs (3DMD). 3DMD is a for-profit small business that spun off of the CBM in 2001 to commercialize instructional materials that were developed for use in these grant-supported workshops. As a result of this partnership, the CBM can readily purchase multiple copies of instructional materials from 3DMD at a deeply discounted price and disperse them to multiple cohorts of teachers in our workshops. Additionally, the CBM and 3DMD share the costs of traveling to multiple science education conferences each year, such as the National Science Teaching Association (NSTA), Wisconsin State Science Teachers (WSST) and National Association of Biology Teachers (NABT) where the vast majority of teachers are recruited for our summer courses.

Modeling Programs for Students. The ultimate goal of CBM teacher workshops is to empower teachers to create a learning environment that will encourage students' confidence in pursuing a STEM career. To significantly impact teaching practice and therefore students' confidence in STEM, we needed to identify a way to encourage and sustain ongoing interactions with teachers over several years (Guskey, 2000). One solution to meeting this challenge of sustained engagement after the first year was the development of student modeling teams that teachers could advise on an annual basis, exploring new topics each year. 
1. The Qualification Phase: This phase is all about practice. Students learn to model the fundamentals of protein structure and function while also reading complex scientific literature and writing a technical abstract on a protein-based research topic.

2. The Research and Design Phase: This is the "real deal." Student teams are paired with a local Research Mentor and begin to study, model and write about the specific protein involved in their mentor's current research project.

\section{The Presentation Phase:}

Time to communicate the science! Students design an engaging and informative poster to tell their protein's molecular story to an audience of both researchers and peers. These posters can be presented at local, regional and national undergraduate-style poster sessions.

Figure 5. The three phases of the Milwaukee-area SMART Team program.

Engaging Students in the Process of Science. By 2000, the CBM had developed a proprietary version of RasMol (molecular visualization software) that could directly create an stl file that could be interpreted by a 3D printer. This development was made possible through an NIH-SBIR project carried out in collaboration with 3D Molecular Designs. That summer, six local teachers who had participated in a previous CBM summer workshop were invited back for a follow-on experience. During that time, Tom Steitz had published the atomic coordinates for the structure of the large ribosomal subunit. These high school teachers designed the first physical models of the ribosome, based on the atomic coordinates published five months earlier by the Steitz lab (Ban et al., 2000) (Figure 3), which were then built at the CBM. As they explored the research topic, the teachers exchanged emails with the Steitz lab as well as several other labs engaged in similar work on the ribosome structure to

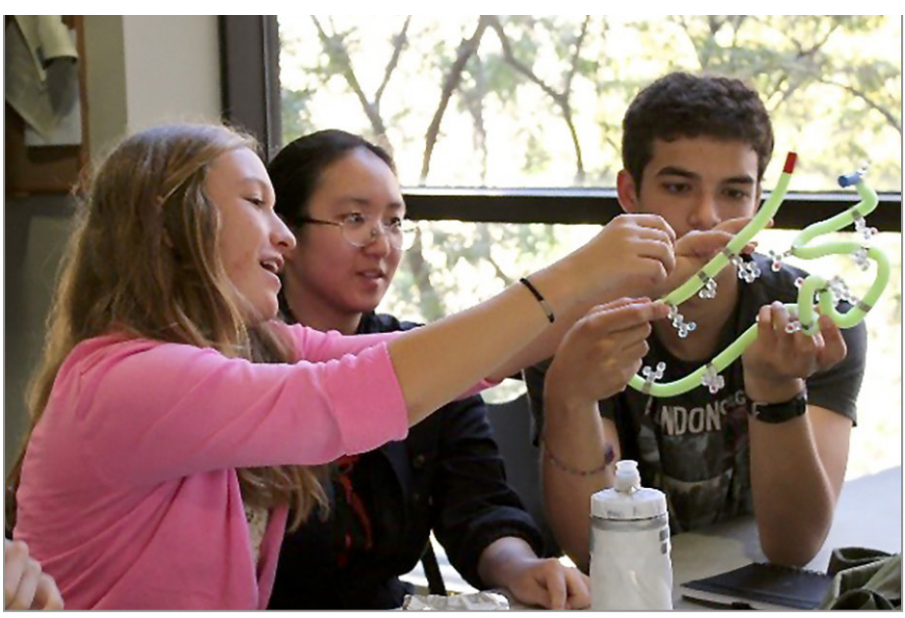

ask questions regarding their design. These teachers experienced the thrill of being involved in a significant but peripheral way (Lave, 1991; Wenger, 1999; Wenger et al., 2011) with researchers working on a cutting-edge research project.

During the summer project, the teachers began telling us they wanted their students to have this same modeling experience. With that, the SMART Teams (Students Modeling A Research Topic) program was born. The very first team formed the following academic year with a high school teacher and three students from Riverside High School in Milwaukee, WI (Goodman, 2002). As this first team was getting organized, the anthrax-laced letters had just been mailed to several members of Congress, prompting the CBM to encourage the team to use this current event as an engaging hook for their first project. This first SMART Team designed models of the three proteins involved in anthrax pathogenesis: the anthrax protective antigen, lethal factor

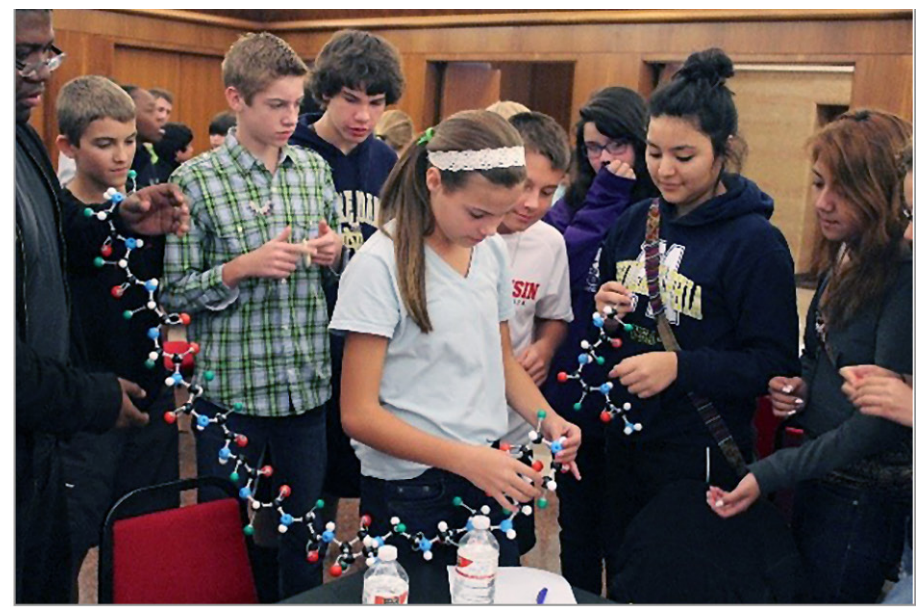

Figure 6. SMART Team students explore how amino acids are joined together to make a protein and then use mini-toobers (foam-covered wire) along with physical models of the twenty amino acid sidechains to examine the principles of chemistry that drive protein folding. 

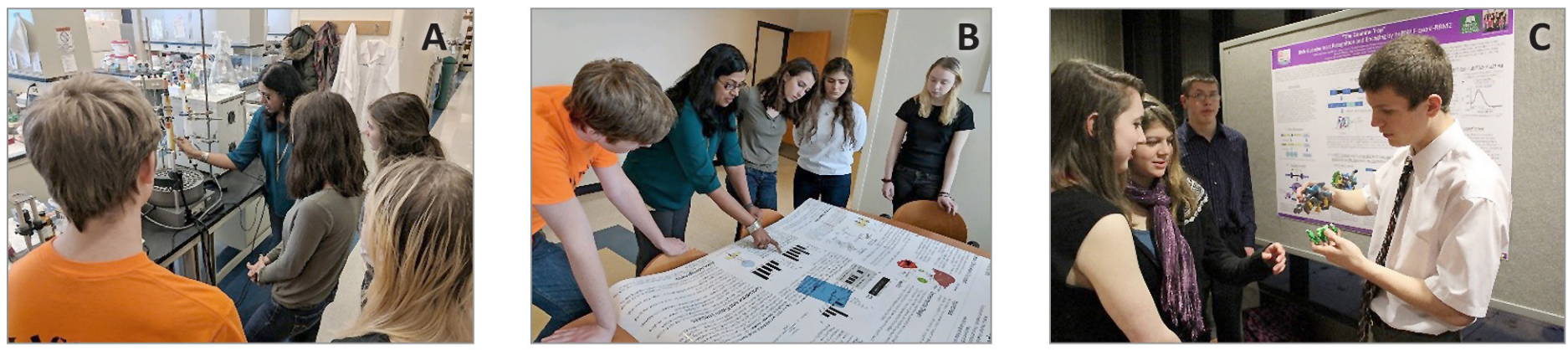

Figure 7. SMART Team students visit their mentor's lab to see what real bench research looks like (A), develop an engaging poster that communicates the molecular story of the protein they modeled (B) and then use the model to tell that story to parents and other SMART Teams at regional poster sessions or to researchers at the annual meeting of the American Society of Biochemistry and Molecular Biology (C).

and edema factor. The model of edema factor was based on atomic coordinates determined by Wei-Jen Tang at the University of Chicago (Drum et al., 2002), in advance of the publication of the paper describing this structure. Dr. Tang used the SMART Team models to explain his work when he was interviewed by the press. In a second remarkable outcome of this first SMART Team, 24 copies of the Team's anthrax protective antigen model were distributed to members of the US House of Representatives Committee on Government Reform when John Young, an anthrax researcher from UW-Madison, testified regarding research on approaches to treat anthrax infections.

What Do SMART Teams Do? SMART Teams are teacherguided groups of students, ages ranging from middle to high school, who collaborate with a local researcher to model a specific protein's molecular story. Because teams are modeling a "research topic," the proteins they are studying are often novel or esoteric, which not only challenges students, but also their teacher advisors. Teams commence their modeling project in fall during phase one, called the "Qualification Phase," that lasts from September through October (Figure 5). During this initial training phase, teams progress through a series of tasks designed to teach them basic concepts of protein structure, how to read and write scientific literature, how to access the Protein Data Bank (PDB) and download protein structure files, and how to use those structure files in software (Jmol) to design a 3D model of a protein (Figure 6). The Qualification Phase tasks are based on a pre-selected and vetted protein topic chosen by CBM staff which is used by all teams. Successful completion of the Qualification Phase tasks ensures that teams are fully prepared to work effectively on a novel research topic with their mentors during the next phase. Working through these tasks, students are practicing several NGSS skills including, connecting structure and function, and analyzing and interpreting data (NGSS Lead States 2013; NSTA 2015). During this phase, the CBM staff review and provide feedback for each team's task.
The "Research and Design" phase generally lasts from November through January. In preparation for this phase, the CBM invites researchers from a variety of local academic institutions to join the program as research mentors. The CBM then coordinates the matching of teams with specific mentors and facilitates the onset of their working relationship. Moving forward, students demonstrate the skills and knowledge developed during the Qualification Phase while working closely with a research mentor to understand their research project and to model the protein that is central to that work. Research mentors provide the teams with primary literature to read and analyze, as well as assist them in the development of an abstract about the molecular story of the protein. Students then use what they've learned about the protein to design a 3D model of it, based on recommendations from the mentor (Figure 7). The team and mentor schedule a lab visit, allowing students to get an intimate, first-hand look at the day-to-day job of a research scientist (Figure 7). Teams are then challenged to model specific components of their topic protein's structure, such as alpha helices, beta sheets, hydrophobic and hydrophilic amino acids, active sites, and more. All of this work is in preparation for communicating their molecular story during the final phase.

The third and final phase, the "Presentation Phase," continues through April. Students develop their scientific literacy and communication skills as they create research-based posters and prepare to tell the stories of their modeling projects during a capstone, undergraduate-style poster session (Figure 7C). Multiple opportunities exist for teams to communicate their science. The CBM hosts a local poster session on the MSOE campus for area teams during the month of March. Additionally, teams are encouraged to set up presentations within their school districts to administrative staff and school board members. In April, a few teams are fortunate to travel to the ASBMB (American Society of Biochemistry and Molecular Biology) annual meeting and present their projects alongside undergraduates. The use of their physical protein model in describing a research project is a distinguishing feature of these poster presentations. CBM 

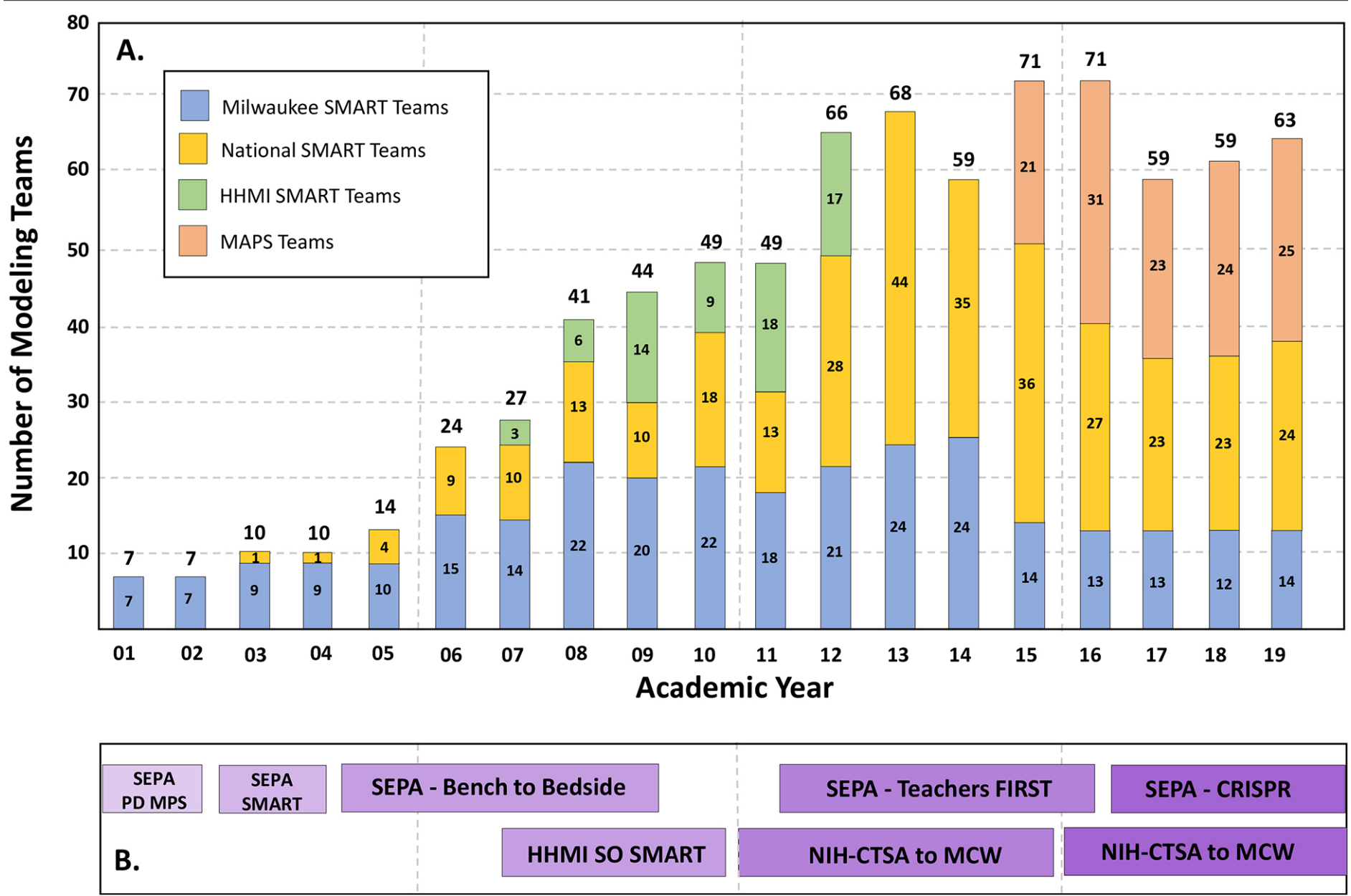

Figure 8. The growth of CBM student modeling teams over the past twenty years. (A) CBM staff coordinate the interactions between Milwaukee-area SMART Teams (blue bars) and local researchers. National SMART Teams (yellow bars) operate outside the Milwaukee area and require teachers to locate research mentors in their area. From 2007 to 2010, an HHMI award funded the further national dissemination of the SMART Team program (green bars). Beginning in 2015, MAPS Teams (tan bars) began using online modeling resources related to a protein selected by CBM staff as they explored a research topic of their own choosing. (B) A series of NIH and HHMI grant awards has provided major funding for the development of these student modeling projects over the past twenty years.

staff print two copies of this model; one is for the team, and the other is presented to the research mentor, who can then use it in a similar way to explain their work to others. During the last two phases of the program, both CBM staff and the research mentor share in the responsibility of providing review and feedback for the teams' tasks. Past SMART Teams projects are archived at: https://cbm.msoe.edu/smartTeams/ smartTeamsArchive.php. Tasks for each SMART Team phase are described at: https://cbm.msoe.edu/smartTeams/ smartTeamsLocal.php.

Teachers have consistently stated that they learn just as much from exploring these molecular stories as their students do, and each new molecular story can become an engaging teaching tool in their science curriculum. Students can benefit from this program in a multitude of ways by honing skills in reading, writing, oral communication and graphic design. Students can gain the confidence to consider pursuing a career in STEM research. Several past SMART Team students have gone on in science fields, including research and teaching. Some continue to give back to the pro- gram as SMART team teachers and mentors.

Evolution of the MAPS (Modeling A Protein Story) Program. To meet the ever-changing needs of students and teachers, the CBM has evolved the program to offer three different variations of the original SMART Team program. The second iteration of the program occurred after our original SMART Team program (blue bars in Figure 8A) grew steadily from seven teams in 2001 to 22 teams in 2008. As the impact of local SMART teams was realized, teachers from across the US participating in CBM summer professional development programs were also interested in providing SMART Team programs for their students, and the National SMART team program developed (yellow bars in Figure 8A). These new National teams are managed differently from local teams in that teachers, rather than CBM staff, determine the goals and timeline for their team's modeling project. National teachers assume the responsibility of finding their own local mentor and facilitating their team's interaction with the lab, with minimal assistance from CBM 


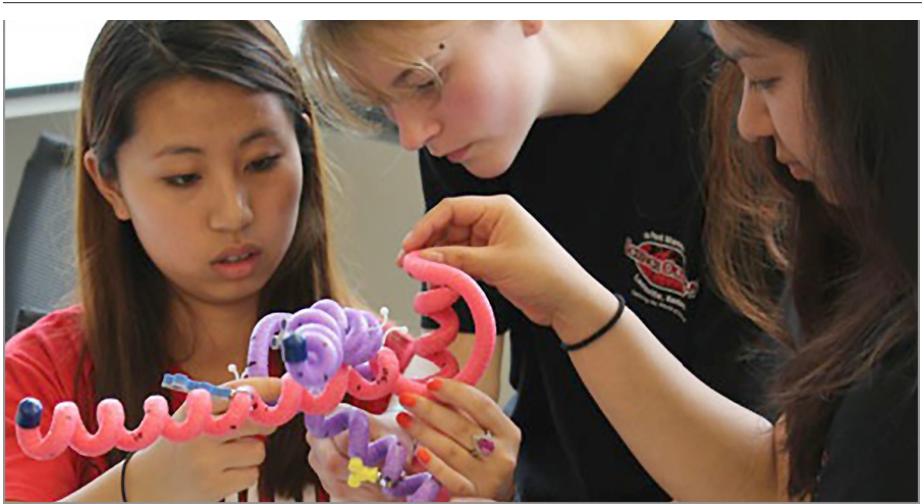

Figure 9. Students participating in the Science Olympiad Protein Modeling Event.

staff. Nevertheless, CBM staff continue to support the efforts of National SMART Teams by reviewing abstracts and model designs, 3D printing models and coordinating the travel of a subset of these teams to capstone presentation events each spring. An HHMI Precollege award focused on the further dissemination of SMART Teams (green bars in Figure 8A) and a Science Olympiad Protein Modeling event. As the HHMI-supported project ended in 2010, these HHMI Teams continued as National SMART Teams.

A series of NIH SEPA grants have supported CBM student modeling programs over the years, and participating teachers and students do so free of charge. However, several challenges still exist for many teams. For example, rural schools may lack easy access to a research institution and struggle with transportation costs and time constraints. Additionally, SMART Team topics are chosen by the mentor, based on current research from the mentor's lab. These topics can often be esoteric and beyond that found in high school level science curricula, at times limiting the team's personal connection to the topic.

With these barriers in mind, we created the third iteration of our student modeling programs-MAPS (Modeling A Protein Story) Teams (orange bars in Figure 8A). The MAPS program consists of the development and optimization of themed multimedia online modules focused on the genetics and structure-function relationships associated with a specific protein relevant to high school bioscience curricula. Teams of students, led by a teacher within a classroom, homeschool, or extracurricular setting and guided by the online modules, progress through hands-on explorations, (many that are the same or similar to those used in SMART) using models and materials such as gene and protein sequence maps, molecular models, protein folding activities, and physical models of proteins. Following progressive investigation of the featured protein, teams choose and explore a protein story extension through which they gain a deeper understanding of a protein by connecting it to a specific research topic of interest. They use molecular visualization software (Jmol) to highlight important features within a virtual protein structure and 3D
No Impact

Little Impact

Moderate

Impact

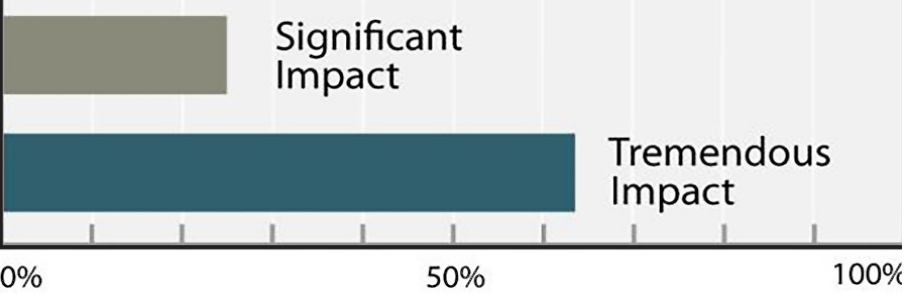

Percent of Total Responses

Figure 10. Teachers were asked to rate the impact of the CBM's Teachers FIRST program on their teaching practice.

print a physical model of their design that is useful in telling their specific molecular story. Currently modules have been developed to study the water channel, aquaporin, oxygen-carrying globins such as myoglobin and hemoglobin, and the critical hormone, insulin. The additional online modeling resources built into our MAPS program allow more schools to access this student-centered modeling program without overburdening limited CBM resources. The CBM hopes to develop additional modules in the future to continue to engage teachers and students.

Since its beginning in 2001, CBM student modeling teams have steadily grown and evolved such that approximately 60-70 middle and high school teams from the US and Canada now participate in this program each year (see Figure 8). Most teachers run the program as an extracurricular activity (some have been successful in getting stipend pay), while others have successfully incorporated this project into a science curriculum during the regular school day. Student teams range in size from just two or three students, to entire classes of $25+$ students. In recent years, the CBM has scaled back the local Milwaukee-area program to host 12-15 local SMART Teams per year, while the other iterations of modeling programs evolved to handle the growing interest in modeling programs nationwide.

Broadening the Impact of Student Modeling. The 3D printing technology that stimulated the development of our outreach programs in the early 2000's initially limited the expansion of this program due to the limited availability and high cost of this technology. Today, that problem has largely disappeared as many schools have acquired low-cost 3D printers that support modeling projects in their schools. But preceding the development of these low-cost printers, the CBM began in 2002 to develop a different protein modeling 


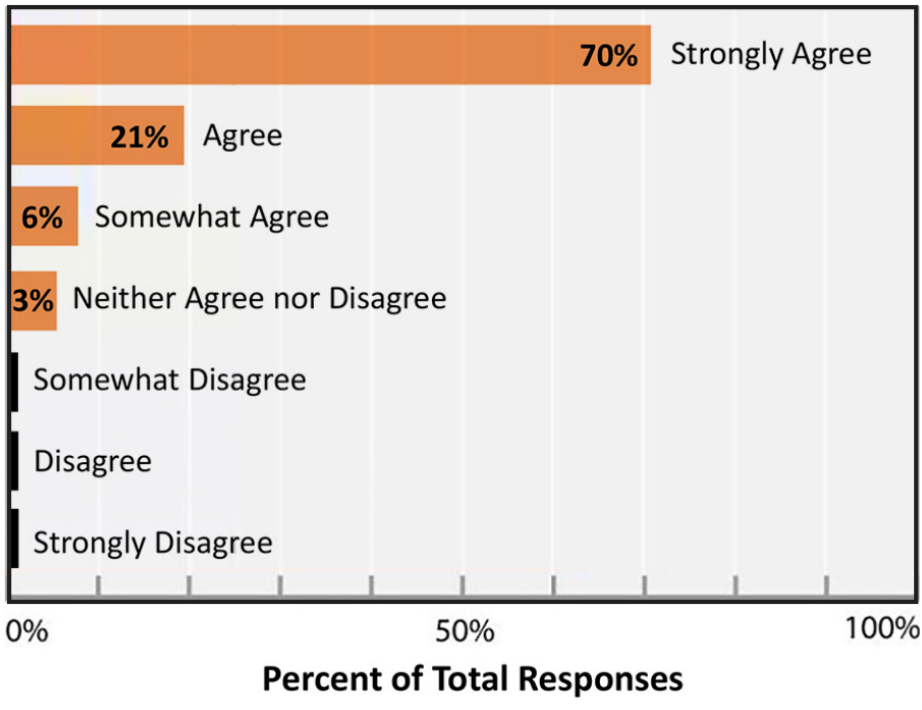

Figure 11. Teachers report that student-centered protein modeling programs contribute to their ongoing professional development.

program that would not require access to $3 \mathrm{D}$ printing technology. An NSF-SBIR award to the CBM's sister organization, 3D Molecular Designs, resulted in the development of technology to produce a novel free-form modeling media called mini-toobers (thin, foam-covered wire). Mini-toobers can be used to accurately model protein folding, based on structural information stored at the Protein Data Bank. Mini-toobers can be cut to any length, retain their shape once folded, but can also be unfolded and reused. As we began using mini-toobers to model protein structure in our summer courses for teachers, we quickly appreciated the power of this new material. At the suggestion of one teacher who coached his school's Science Olympiad team, the CBM developed a Protein Modeling event for this national-scale science competition (Figure 9). Fifteen years later, this free-form protein modeling program has become an important way for us to broaden the impact of our current SEPA projects. For example, our current SEPA project is focused on the Science and Ethics of CRISPR-based Genome Editing. Many of the same instructional materials that have been created to introduce teachers to CRISPR technology have been incorporated into the online modeling resources that are being used by Science Olympiad students. Beginning in 2007, an HHMI Precollege award (Figure 8B) supported the development and national dissemination of this program. It became a regular scored Science Olympiad event in 2009, with approximately 2000 teams of high school students participating each year (Figure $8 \mathrm{~A})$. For the past ten years, we have used this event to more broadly disseminate the instructional materials developed in three successive SEPA awards.

Documenting the Impact of our Programs. We have documented the impact of our outreach program on both teachers and their students throughout the evolution of these pro- grams over the past twenty years. This documentation has most commonly taken the form of surveys administered immediately at the conclusion of a summer course for teachers, or at the end of a SMART Team modeling project. As might be expected for a program with such longevity, the results of these surveys have been overwhelmingly positive. For example, to document the impact of our summer professional development program on teachers, we asked three cohorts of teachers who had participated in our Teachers First summer course to rate the impact of that course on their teaching practice. Seventy-two teachers were surveyed and forty-eight responses were received. Eighty-eight percent of the responding teachers reported that the program had either "tremendous" or "significant" impact on their teaching practice (Figure 10). In a related survey, eighty-five percent of teachers reported continued use of the project's instructional tools in their classroom, up to five years after participation in the program. These results indicate to us that teachers find something of value in our professional development programs and demonstrate that value by returning to subsequent summer workshops and by incorporating the instructional tools that were introduced in the workshops into their classrooms.

A subset of teachers who participate in our summer professional development courses go on to organize SMART or MAPS teams in their schools. We have also routinely surveyed both teachers and students who participate in these student-centered modeling programs. For example, in a 2010 SMART Teams survey, teachers and students were asked if they could go back in time, would they participate in the program again. In both groups the overwhelming majority ( $94 \%$ or more) responded in the affirmative. This survey was administered at the end of a SMART Team season, when both teachers and students were well aware of the effort and time commitment that this program requires.

In other surveys conducted over the years, we have found that:

- $78 \%$ of teachers who start SMART Teams in their schools continue to involve their students in modeling programs for multiple years. Attrition most commonly is due to retirement or transfer to another position.

- This program has engaged well over 120 research mentors over the years. Since 2010, approximately $46 \%$ of mentors have returned to participate in the program for multiple years. A number of research mentors engage one or more of their graduate students in the mentoring process as well.

- In the 2010 survey of research mentors, twelve out of thirteen surveyed $(92.3 \%)$ indicated that the model created by the students was useful in their teaching and research projects. 
When the CBM began to develop its outreach program twenty years ago, our primary mission was to create professional development programs for teachers. Because the CBM staff at that time did not include anyone with classroom teaching experience at the high school level, we did not feel prepared to create modeling programs for students. As described previously in this paper, it was the teachers who convinced us that we should create a modeling program for students. As a result, the teachers have helped us develop and evolve these various modeling programs that are often seen solely as student-centered activities. But the CBM has always viewed these student modeling programs as another way to keep teachers engaged with us and to continually add to their development as professional educators. To document the impact of our student-centered modeling programs on the professional development of our teachers, we surveyed over 60 teachers who had advised student modeling programs in their schools. Of the 33 teachers who responded, $90.9 \%$ reported that they either Strongly agree or Agree that these programs provide them with meaningful ongoing professional development (Figure 11).

Other insights into the impact of our student modeling program that were revealed by this survey include:

- $\quad 90.9: \%$ of respondents reported participating in the program for more than one year, with an average participation length of six years. Teachers reported common obstacles to continued participation, including increased administrative workload, transitions of teachers to new schools, and retirement.

- $83.9 \%$ of respondents strongly agreed or agreed that modeling programs nurture students' confidence in reading scientific literature.

- $86.7 \%$ of respondents strongly agreed or agreed that modeling programs encouraged students to pursue a career in STEM.

- $93.5 \%$ of respondents strongly agreed or agreed that modeling programs encourage students to explore difficult concepts at a deeper level and encourage them to try new things they didn't think they could do.

- $96.8 \%$ of respondents strongly agreed or agreed that modeling programs encourage students to ask relevant questions.

Aside from the results of many surveys of our teachers and students, as exemplified by the data reported in figures 10 and 11, we have not engaged in an effort to rigorously study and identify the facets of our program that contribute to its success. Instead, we have used the constant feedback from teachers to continually modify and improve our programs. We are aware of the many professional science education researchers within the SEPA community who have developed innovative and rigorous evaluation protocols for their projects. These approaches could almost certainly be applied to our programs to provide more rigorous evidence of positive impact. At the same time, we have always appreciated the diversity within the SEPA community, and its willingness to embrace programs such as ours where the focus is more on the development and broad dissemination of effective programs than on an education research project.

\section{Modeling Programs Are Beneficial to All Stakeholders.}

One essential feature of a successful outreach program is that it must be valued by the various stakeholders impacted by the program (Guskey, 2000). The CBM modeling program has succeeded over the past twenty years because it is perceived as offering value to multiple stakeholders, including teachers, students, researchers, schools and parents.

- Teachers value the ongoing professional development and content knowledge they gain as they advise a new student modeling project year after year. In a 2009 interview, teachers were asked their main reason for participating in the program. Teachers mentioned their love of science, their need to stay connected to the field, and the excitement of working with a practicing research scientist.

- Students value the opportunity to participate in a peripheral but significant way in the process of science outside of the traditional classroom (Lave 1991, Wenger 1999, Wenger et. al. 2011). In a 2009 interview, students were asked their main reason for participating in the program. Students cited an interest in science, encouragement from their teacher, and positive reviews of the program from fellow classmates. Students often share that their experience on a SMART Team gave them a significant "leg up" as they transitioned from high school to college.

- Researchers value not only the ability to give back by sharing their expertise and enthusiasm for biological research, but also benefit from including mentoring in the outreach/broader impacts component of research proposals.

- Schools and Parents value the unique experience their students gain by exploring real science, as it is being practiced in an active research lab.

The CBM has collected many quotes from teachers and students commenting on their experiences with our programs. Some of those quotes can be found at https://cbm. msoe.edu/smartTeams/smartTeamsQuotes.php. Selected examples of these comments from our stakeholders are provided in Figure 12. 


\section{What Are Our Stakeholders Saying?}

\section{Students}

"It has shown me that even a young high school student can become a member of the scientific community."

"It has taught me teamwork as well as it's okay if you do not know something."

"SMART Team helped me learn what I want to do after high school."

"It helped me see different parts of a scientist's job and how research comes together in the end to tell a story."

"The SMART Team program taught me what research was all about. It also taught me that you always have support and not everyone knows all the answers. One has to ask questions to learn, even our mentor still has questions. By participating in SMART Team I have come to enjoy science/biology more and will continue down that career path in college."

\section{Teachers}

"Building that interaction with the students- it's incredible. It also actually helps me be a better teacher, because part of teaching is remembering how you learn. I'm learning something new every single time I do SMART Teams."

"The students that have been with me for 2-3 years are learning how to ask questions and probe for deeper knowledge. They want to know how the systems are connected. They are seeing the bigger picture and wanting to learn more about it. SMART Teams has really opened their eyes to be able to have the tools to access the knowledge."

"I love the story telling to go along with the models. I will try to incorporate that this year. The course has had a big impact on me in that I think it is important to have a purpose, a story, to go along with the information we "pass on" in the traditional sense. I also think that I should not lead the class as much as provide students models and materials to help them build some of their knowledge themselves.

\section{Research Mentors}

"I actually think this is one of the most important things that I can do; to mentor the future scientist."

"I grew up in a really small town, and research was something that somebody else did and there were no role models, so I think its just astounding that these young people have these opportunities to take advantage of the expertise of a faculty, to see the facilities... I can't imagine doing Pymol when I was their age, it's actually pretty incredible."

Figure 12. Quotes from our stakeholders. 


\section{DISCUSSION}

The Power of Partnerships. An important aspect of the CBM's success in sustaining its outreach program has been its ability to establish meaningful partnerships with members throughout the research and educational communities. The most important of these various partnerships are those we have established with, and among, teachers. Without teachers who have been willing to work both with us and each other on an ongoing basis in an authentic community of learners, our program would not have thrived this many years. Innovative teachers interested in implementing new teaching pedagogies can often feel isolated in their individual schools (Guskey, 2000). In the CBM, teachers discover like-minded educators who often become life-long colleagues and friends, sharing instructional strategies and ongoing support and encouragement. The community of teachers that has grown up around our summer courses and modeling programs continues to provide invaluable resources and energy that drives CBM programming forward. Many of our veteran teacher participants continue to engage as members of teacher advisory boards for new course development, as field testers for new modeling activities, or as co-presenters of courses and workshops.

The CBM also values its researcher partners. Milwaukee is home to a number of research institutions, and researchers have been recruited from these institutions to serve not only as research mentors for local SMART teams, but also as guest lecturers at summer courses and as content knowledge experts in the development of instructional materials. These collaborations have provided educators in our professional development programs access to scientific expertise that it would be otherwise difficult for them to acquire.

Another unique partnership that has contributed significantly to the success of CBM modeling programs is our synergistic relationship with the small business, 3D Molecular Designs (3DMD). 3DMD was first started with funding from an NIH SBIR award in 2001. A key outcome of that initial SBIR award was the creation of RP-RasMol, the first molecular visualization program that created an output file that could be recognized by a $3 \mathrm{D}$ printer. Without the creation of RP-RasMol, we would not have been able to launch the protein modeling programs that have become a major component of our outreach efforts. 3DMD supports the efforts of the CBM by further modifying the designs for instructional materials that are prototyped in our work with teachers, and then providing multiple copies of these materials to us for use in subsequent summer courses. This partnership with 3DMD has significantly expanded the impact of our program to teachers. In addition to making these materials available for sale to teachers across the US, 3DMD contributes classroom sets of these materials to the MSOE Modeling Lending Library (https://cbm.msoe.edu/lendingLibrary). Teachers can borrow these model sets to use in their classrooms for a two-week period, at no cost except for return postage.

Partnerships with other outreach programs, especially those supported by NIH-SEPA projects, represent yet another example of how an outreach program can expand its reach. The networking that results at the annual NIH SciEd Conference has been a rich source of collaborations with other SEPA projects. These collaborations have proven to be mutually beneficial to the programs involved and have contributed new ideas and energy to our program.

Additional Challenges to Sustained Outreach. In addition to challenges addressed earlier, an equally important challenge that must be met to sustain an outreach program is to maintain the interest and engagement of teachers in the program. If a program fails to provide new content or pedagogy, teachers may benefit from their initial exposure to the program, but then move on to a different one. The CBM's key to sustaining teacher interest in our program has been the use of 3D printing technology to support the development of new student-centered modeling activities and molecular stories on a regular basis. As teachers leverage the power of a physical model of a protein to capture students' interest and meaningfully involve them in the work of a local researcher, they too are gaining valuable new content knowledge that they can utilize in their classrooms, benefiting students for years to come. Thus, the CBM leverages modeling programs to improve professional development of educators by 1) engaging educators on an ongoing basis, 2) providing opportunities for gaining content knowledge in current fields of research and 3) creating models that can be used in the classroom to further enhance student engagement/learning. These features all contribute to ongoing engagement of educators, an identified best practice in professional development (Guskey, 2000). Additionally, the CBM has allowed for the evolution of student modeling programs in order to make them more accessible to a variety of both teachers and students.

\section{Accessibility of Modeling Programs and Engaging Under-} represented Students. It has long been a CBM goal to engage more underrepresented minority students and teachers in our outreach programs. To make our outreach program more accessible to the underserved population in the Milwaukee area, we have reached out and formed partnerships with Milwaukee Public Schools and the Clinical and Translational Science Institute (CTSI) of Southeast Wisconsin. The goal of these partnerships is to collaborate on ways to identify both teachers and students from Milwaukee Public schools who might be interested in or would benefit from modeling programs. We can cite multiple examples of anecdotal evidence that underrepresented teachers and students have benefited enormously from these programs. These examples come from our work with both teachers and students 
in urban Milwaukee, Chicago Public Schools and the Bronx in New York City. In each case, underrepresented student members of modeling teams have completed a protein modeling project and traveled to an annual national meeting of the American Association of Biochemistry and Molecular Biology (ASBMB) to present their work in poster sessions alongside undergraduate and post-doctoral researchers from other universities.

While we are confident these modeling programs can benefit underrepresented students, we have not yet been able to disproportionately target our programs to this demographic, as funding agencies would wish. The major challenge to this goal lies in the systematic disparities that are well documented to exist in under-served urban school systems. The success of each modeling team is heavily tied to an exceptional teacher with career stability who believes in the abilities of their students. Through twenty years of modeling programs, we have encountered many exceptional teachers in school districts that serve primarily underrepresented students. However, several challenges exist to retaining these exceptional teachers and students: (i) an abnormally high turnover rate of teachers in these urban districts, as better-resourced suburban school districts actively recruit these exceptional teachers, (ii) an accelerated burn-out rate of overloaded teachers working in difficult teaching environments, and (iii) instability in the student population, as parents move and search out better educational opportunities for their children.

Nevertheless, we remain committed to this goal of engaging more underrepresented teachers and students in our program. As a current example of these ongoing efforts, we are working with a Milwaukee public high school to pilot a new approach to teaching freshmen biology using handson instructional materials from the CBM. This new course includes a student-centered protein modeling project as a capstone experience. We are hopeful that this new way of teaching biology will be disseminated to other schools in this urban school district.

\section{SUMMARY}

Over the past twenty years, the MSOE Center for BioMolecular Modeling has created a science outreach program that has enriched the content knowledge of teachers in the molecular biosciences and engaged high school students in protein modeling projects that have introduced them to the process of science as it is being practiced in active research labs. Through these programs, teachers and students alike have gained experience in (i) using models to explore the invisible world of proteins, (ii) analyzing, writing and reviewing primary scientific literature, (iii) utilizing Jmol software to design 3D models of proteins with features that aid in the telling of the protein's story, (iv) designing undergraduate-style posters and communicating the protein's story to a larger audience. Participation in these modeling programs aligns with several of the Next Generation Science Standards and offers unique insight into the process of science and the career of a research scientist. As the cost of 3D printing technology continues to fall and more teachers become aware of the power of using physical models of proteins in their classrooms, we anticipate that more and more schools will adopt some version of the protein modeling programs described here.

\section{AUTHOR INFORMATION Corresponding Author}

Tim Herman. Center for BioMolecular Modeling, Milwaukee School of Engineering. 1025 N. Broadway, Milwaukee, WI, 53202. (414) 277-7529. herman@msoe.edu

\section{Author Contributions}

The manuscript was written through contributions of all authors. All authors have given approval to the final version of the manuscript.

\section{ACKNOWLEDGMENTS}

The authors would like to acknowledge the many contributions of both teachers and research mentors to our programs. Without their expertise, enthusiasm and dedication to their students, our programs would not be successful. We would also like to acknowledge Mike Warden for his passion and precision in $3 \mathrm{D}$ printing the models. Finally, we would like to acknowledge the contributions of our partners at 3D Molecular Designs. Their help in providing instructional materials to our teachers and in providing logistical support for our Science Olympiad Protein Modeling event have made these programs possible.

\section{FUNDING SOURCES}

Support for this work was provided by a series of NIH/ NIGMS Science Education Partnership Awards (including R25 OD023723), a HHMI Pre-college award and a series of CSTA awards to the Medical College of Wisconsin.

\section{ABBREVIATIONS}

3DMD: 3D Molecular Designs; ASBMB: American Society of Biochemistry and Molecular Biology; CBM: Center for BioMolecular Modeling; CCC: Cross-Cutting Concepts; CTSI: Clinical and Translational Science Institute; DCI: Disciplinary Core Idea; NABT: National Association of Biology Teachers; NGSS: Next Generation Science Standards; NIH: National Institutes of Health; NSF: National Science 
Foundation; NSTA: National Science Teaching Association; PDB: Protein Data Bank; SEP: Science and Engineering Practice; SEPA: Science Education Partnership Award; SMART: Students Modeling A Research Topic; WSST: Wisconsin State Science Teachers

\section{REFERENCES}

Ainsworth, S. (1999). The functions of multiple representations. Computers and Education, 33(2-3), 131-152. https://doi. org/10.1016/S0360-1315(99)00029-9

Babilonia-Rosa, M. A., Kuo, H. K., and Oliver-Hoyo, M. T. (2018). Using 3D printed physical models to monitor knowledge integration in biochemistry. Chemistry Education Research and Practice, 19(4), 1199-1215. https://doi. org/10.1039/C8RP00075A

Bain, G. A., Yi, J., Beikmohamadi, M., Herman, T. M., and Patrick, M. A. (2006). Using physical models of biomolecular structures to teach concepts of biochemical structure and structure depiction in the introductory chemistry laboratory. Journal of Chemical Education, 83(9), 1322. https:// doi.org/10.1021/ed083p1322

Ban, N. (2000). The complete atomic structure of the large ribosomal subunit at 2.4 A resolution. Science, 289(5481), 905-920. https://doi.org/10.1126/science.289.5481.905

Cooper, A. K., and Oliver-Hoyo, M. T. (2017). Creating 3D physical models to probe student understanding of macromolecular structure: Creating 3D Physical Models. Biochemistry and Molecular Biology Education, 45(6), 491-500. https:// doi.org/10.1002/bmb.21076

Drum, C. L., Yan, S.-Z., Bard, J., Shen, Y.-Q., Lu, D., Soelaiman, S., Grabarek, Z., Bohm, A., and Tang, W.-J. (2002). Structural basis for the activation of anthrax adenylyl cyclase exotoxin by calmodulin. Nature, 415(6870), 396-402. https://doi.org/10.1038/415396a

Gabel, D., and Sherwood, R. (1980). The effect of student manipulation of molecular models on chemistry achievement according to Piagetian level. Journal of Research in Science Teaching, 17(1), 75-81. https://doi.org/10.1002/ tea.3660170112

Gilbert, J. K. (2005). Visualization: A metacognitive skill in science and science education. In J. K. Gilbert (Ed.), Visualization in Science Education (pp. 9-27). Springer Netherlands. http://link.springer.com/10.1007/1-4020-3613-2_2

Gilbert, J. K., and Justi, R. (2016). Chapter 4: Approaches to modelling-based teaching. In Modelling-based Teaching in Science Education. Springer Berlin Heidelberg.

Goodman, S. (2002). Put your lab in a different class, Nature, 420, $12-14$.

Guskey, T. R. (2000). Evaluating professional development. Corwin Press.
Harris, M. A., Peck, R. F., Colton, S., Morris, J., Chaibub Neto, E., and Kallio, J. (2009). A combination of hand-held models and computer imaging programs helps students answer oral questions about molecular structure and function: A controlled investigation of student learning. Cell Biology Education, 8(1), 29-43. https://doi.org/10.1187/cbe.0807-0039

Herman, T., Colton, S., and Franzen, M. (2008). Rethinking outreach: Teaching the process of science through modeling. PLoS Biology, 6(4), e86. https://doi.org/10.1371/journal. pbio. 0060086

Herman, T., Morris, J., Colton, S., Batiza, A., Patrick, M., Franzen, M., and Goodsell, D. S. (2006). Tactile teaching: Exploring protein structure/function using physical models. Biochemistry and Molecular Biology Education, 34(4), 247254. https://doi.org/10.1002/bmb.2006.494034042649

Larsson, C., and Tibell, L. A. E. (2015). Challenging students' intuitions - The influence of a tangible model of virus assembly on students' conceptual reasoning about the process of self-assembly. Research in Science Education, 45(5), 663-690. https://doi.org/10.1007/s11165-014-9446-6

Lave, J. (1991). Situating learning in communities of practice. In L. B. Resnick, J. M. Levine, and S. D. Teasley (Eds.), Perspectives on Socially Shared Cognition (pp. 63-82). American Psychological Association. http://dx.doi. org/10.1037/10096-003

Loertscher, J., Green, D., Lewis, J. E., Lin, S., and Minderhout, V. (2014). Identification of threshold concepts for biochemistry. Cell Biology Education, 13(3), 516-528. https://doi. org/10.1187/cbe.14-04-0066

NGSS Lead States. (2013). Next Generation Science Standards: For states, by states. National Academies Press.

NSTA. (2015). NGSS for all students (O. Lee, Ed.). National Science Teachers Association.

Passmore, C., Gouvea, J. S., and Giere, R. (2014). Models in science and in learning science: Focusing scientific practice on sense-making. In M. R. Matthews (Ed.), International Handbook of Research in History, Philosophy and Science Teaching (pp. 1171-1202). Springer Netherlands. https:// doi.org/10.1007/978-94-007-7654-8_36

Roberts, J. R., Hagedorn, E., Dillenburg, P., Patrick, M., and Herman, T. (2006). Physical models enhance molecular three-dimensional literacy in an introductory biochemistry course*. Biochemistry and Molecular Biology Education, 33(2), 105-110. https://doi.org/10.1002/ bmb.2005.494033022426

Wenger, E. (1999). Communities of Practice: Learning, Meaning and Identity. Cambridge University Press.

Wenger, E., Trayner, B., and de Laat, M. (2011). Promoting and assessing value creation in communities and networks: A conceptual framework. Ruud de Moor Centrum. 